\title{
Efficacy and Safety of Up-dosing Antihistamines in Chronic Spontaneous Urticaria: A Systematic Review of the Literature
}

\author{
Iriarte Sotés $\mathrm{P}^{1 *}$, Armisén $\mathrm{M}^{2 *}$, Usero-Bárcena $\mathrm{T}^{3 *}$, Rodriguez Fernández $\mathrm{A}^{4}$, Otero Rivas $\mathrm{MM}^{5}$, \\ Gonzalez $\mathrm{MT}^{2}$, Meijide Calderón $\mathrm{A}^{6}$, Veleiro $\mathrm{B}^{7 *}$, from Urtigal, the Galician Group of Interest in Urticaria
}

\begin{abstract}
'Allergology Department, Complexo Hospitalario Universitario de Ferrol, Spain ${ }^{2}$ Allergology Department, Complexo Hospitalario Universitario de Santiago, Spain ${ }^{3}$ Dermatology Department Complexo Hospitalario Universitario de Ferrol, Spain ${ }^{4}$ Allergology Department, Centro de Especialidades Mollabao, Pontevedra, Spain ${ }^{5}$ Dermatology Department, Hospital Universitario Lucus Augusti, Lugo, Spain ${ }^{6}$ Allergology Department, Complexo Hospitalario Universitario de Vigo, Spain ${ }^{7}$ Allergology Department, Complexo Hospitalario Universitario A Coruña, Spain

*These authors participated equally in the preparation of this manuscript.
\end{abstract}

J Investig Allergol Clin Immunol 2021; Vol. 31(4): 282-291

doi: 10.18176/jiaci.0649

\section{Abstract}

Background: According to current guidelines, oral antihistamines are the first-line treatment for chronic spontaneous urticaria (CSU). Up-dosing antihistamines to 4-fold the licensed dose is recommended if control is not achieved. Such indications are based mainly on expert opinion. Objectives:To critically review and analyze clinical evidence on the efficacy and safety of higher-than-licensed dosage of second-generation oral antihistamines in the treatment of CSU.

Material and Methods: A systematic literature review was performed following a sensitive search strategy. All articles published in PubMed, EMBASE, and the Cochrane Library between 1961 and October 2018 were examined. Publications with CSU patients prescribed secondgeneration antihistamines in monotherapy compared with placebo, licensed dosages, and/or higher dosages were included. Articles were evaluated by peer reviewers. Quality was evaluated using the Jadad and Oxford scores.

Results: We identified 337 articles, of which 14 were included in the final evaluation (fexofenadine, 6; cetirizine, 2; levocetirizine and desloratadine, 1; levocetirizine, 1; rupatadine, 2; ebastine, 1; and bilastine, 1). Only 5 studies were placebo-controlled. The number of patients included ranged from 20 to 439. The observation lapse was $\leq 16$ weeks. High fexofenadine doses produced a significant dosedependent response and controlled urticaria in most patients. Cetirizine, levocetirizine, rupatadine, and bilastine were more effective in up-dosing. The most frequent adverse events were headache and drowsiness.

Conclusion: The low quality and heterogeneity of the articles reviewed made it impossible to reach robust conclusions and reveal the need for large-scale randomized clinical trials.

Key words: Chronic urticaria. Antihistamines. Treatment. Up-dosing. Efficacy. Safety. Systematic review.

\section{Resumen}

Antecedentes: Según las guías actuales, los antihistamínicos orales de segunda generación constituyen el primer escalón terapéutico en la urticaria crónica espontánea (UCE). Si el control no se alcanza con la dosis licenciada en ficha técnica, se recomienda aumentarla hasta cuatro veces al día. Estas indicaciones están basadas principalmente en opiniones de expertos.

Objetivo: Realizar una revisión crítica y un análisis de la evidencia clínica sobre la eficacia y seguridad de dosis superiores a las autorizadas de antihistamínicos orales administradas para el tratamiento de la UCE.

Material y Métodos: Se realizó una revisión sistemática de los artículos publicados en PubMed, EMBASE, y Cochrane Library entre 1961 y octubre de 2018. Se incluyeron publicaciones de pacientes con UCE tratados con antihistamínicos de segunda generación en monoterapia comparando dosis licenciadas con dosis superiores controladas o no con placebo. Los artículos fueron revisados por pares. Su calidad se evaluó siguiendo la puntuación de Jadad y Oxford.

Resultados: Identificamos un total de 337 artículos, en la evaluación final seleccionamos 14; 6 sobre fexofenadina, 2 de cetirizina, levocetirizina, rupatadina y desloratadina, y 1 de ebastina y bilastina. El número de pacientes incluidos en los estudios se encontraba en un rango entre 20 y 439. El tiempo de observación fue $\leq 16$ semanas. Solo 5 estudios estaban controlados con placebo. Dosis altas de fexofenadina produjeron una respuesta significativa y controlaron la urticaria en la mayoría de los pacientes. Cetirizina, levocetirizina, rupatadina y bilastina mostraron mayor eficacia al subir la dosis. Los efectos secundarios más frecuentemente referidos fueron cefalea y somnolencia.

Conclusiones: La baja calidad y heterogeneidad de los artículos revisados hace imposible obtener conclusiones válidas y nos indica la necesidad de desarrollar ensayos clínicos aleatorizados a mayor escala.

Palabras clave: Urticaria crónica. Antihistamínicos. Tratamiento. Up-dosing. Eficacia. Seguridad. Revisión sistemática. 


\section{Introduction}

Chronic spontaneous urticaria (CSU) is characterized by recurrent itchy wheals and/or angioedema that persist for at least 6 weeks. Its origin remains unknown. CSU is thought to affect $0.5 \%-1 \%$ of the general population and is more common in adults than in children. The female:male ratio is $2: 1$ [1].

The underlying cellular and molecular mechanisms are unclear, although there is evidence of basophil and mast cell participation. Histamine and other mast cell mediators (eg, platelet activating factor, cytokines, proteases, kinins) are the main mediators of this process [2]. The chronic course of CSU and the lack of a well-defined etiology considerably affect patient quality of life in terms of marked physical, emotional, and social impact.

According to recent guidelines, second-generation antihistamines are the first-line symptomatic treatment for CSU. These drugs act as inverse agonists against the $\mathrm{H} 1$ receptor, stabilizing it in its inactive form. However, in the case of patients with inadequate control of symptoms at licensed dosages, European guidelines, which are based on expert opinion, recommend up-dosing to 4-fold as the second step in [3]. Omalizumab is recommended in those cases where control is not achieved, [4].

We analyzed available data on the efficacy of secondgeneration antihistamines at higher doses than licensed to treat CSU with the aim of determining whether there was sufficient information to accurately ascertain the efficacy and safety profile of this approach.

\section{Material and Methods}

We performed a systematic literature review following the PRISMA checklist and the recommendations of the Cochrane Collaboration.

\section{Search Strategy}

With the help of an expert documentalist, we searched PubMed, EMBASE, and the Cochrane Database to identify studies published from 1961 to October 2018. We used MeSH and free-text terms including histamine $H 1$ antagonists, nonsedating, and chronic spontaneous urticaria.

\section{Eligibility Criteria}

We included studies in English or Spanish that met all of the following criteria: (1) age $>12$ years with CSU with or without histaminergic angioedema, dermographism, or delayed pressure urticaria; (2) treatment based on a regular regimen (not on demand) with second-generation antihistamines (cetirizine, loratadine, ebastine, desloratadine, bilastine, levocetirizine, rupatadine, fexofenadine) in monotherapy (not combined with antihistamines or other drugs); (3) comparison with placebo, licensed dosage, and/or higher dosage and comparable information on efficacy and safety; (4) randomized controlled trials and prospective and retrospective observational studies.

Studies of patients with other pruritic dermatological conditions or inducible urticaria other than delayed pressure urticaria and dermographism were excluded.

\section{Study Selection}

Studies were selected by researchers in independent pairs (MA and BV; MO and PI; TU and GP; AR and TG). The articles retrieved were distributed among the pairs of reviewers. After removal of duplicates in the first selection round, each pair of reviewers selected the articles by title and abstract based on the inclusion and exclusion criteria. Those studies that fulfilled the inclusion criteria (at least initially) and those without an abstract were then evaluated in a second selection process. In the case of multiple studies analyzing the same patients, the one with the most comprehensive population was selected. Each selected paper was evaluated individually. Discrepancies in the selection processes were resolved by discussion with an expert methodologist.

\section{Data Extraction and Quality Assessment}

The reviewers also extracted data and summarized the information in specific tables. The characteristics recorded from each study were as follows: (1) first author's name and year of publication, type of study, and time of observation; (2) patient data, such as sample size, age range, and sex; (3) intervention-related data, such as the type of antihistamine, dosages, and time of exposure; (4) patient outcomes, namely, efficacy (including scales used for evaluation) and adverse effects.

The quality of the studies was evaluated using the levels of evidence of the Oxford Center for Evidence-based Medicine [5] and the Jadad scale [6]. The latter evaluates the quality of randomization, double blinding, and losses to follow up on a scale of 0 to 5 . Studies with 5 points are considered high-quality and fewer than 3 points as poor-quality.

\section{Statistical Analysis}

A table of evidence (Table 1) was produced to describe the main characteristics of the studies. A qualitative analysis was performed with the information collected by type of study, population, study quality, and specific results.

Given the lack of homogeneity between the studies, we decided not to perform a meta-analysis.

\section{Results}

We initially identified 337 articles; 73 were duplicates. After analyzing the remaining 264 according to the inclusion and exclusion criteria, 254 were excluded ( 225 by title and abstract and 29 after a close reading). Four articles were included based on a manual secondary search. Finally, 14 articles were analyzed in detail. The PRISMA template for the study flow chart is shown in the Figure.

The main characteristics and results of the 14 studies included in the present review are shown in Tables 1 and 2. The studies differ in population size, type of antihistamines used, design, and quality. Six studies focused on fexofenadine (maximum dose, $720 \mathrm{mg}$ ), 2 on cetirizine, 1 on levocetirizine and desloratadine, 1 on levocetirizine, 2 on rupatadine, 1 on ebastine, and 1 on bilastine. Only 5 studies -3 on fexofenadine and 2 on rupatadine - were placebo-controlled. The number 
Table 1. Global Evidence

\begin{tabular}{|c|c|c|c|c|c|c|c|c|c|c|c|}
\hline Study & Design & $\begin{array}{l}\text { No. of } \\
\text { Patients } \\
\text { (With- } \\
\text { drawn) }\end{array}$ & $\begin{array}{l}\text { Female } \\
\text { Sex, }\end{array}$ & Age, y & $\begin{array}{l}\text { Dura- } \\
\text { tion, } \\
\text { wk }\end{array}$ & Antihistamine & $\begin{array}{l}\text { Daily } \\
\text { Dosage, } \\
\text { mg }\end{array}$ & $\begin{array}{l}\text { Efficacy } \\
\text { Measures }\end{array}$ & Safety & Oxford & Jadad \\
\hline $\begin{array}{l}\text { Paul et al } \\
1998 \text { [9] }\end{array}$ & $\begin{array}{l}\text { Multicenter } \\
\text { Randomized } \\
\text { Double-blind } \\
\text { Placebo- } \\
\text { controlled } \\
\text { Parallel }\end{array}$ & $222(76)$ & $58 \%$ & $\geq 18$ & 6 & Fexofenadine & $\begin{array}{l}60 \\
120 \\
180 \\
240\end{array}$ & $\begin{array}{l}\text { PS }(0-3) \\
\text { NWS }(0-4) \\
\text { TSS }(0-7) \\
\text { Perception of } \\
\text { medication } \\
\text { effectiveness. } \\
\text { Severity of } \\
\text { disease by } \\
\text { physician }\end{array}$ & Yes & $2 a$ & 3 \\
\hline $\begin{array}{l}\text { Finn et al } \\
1999 \text { [7] }\end{array}$ & $\begin{array}{l}\text { Multicenter } \\
\text { Randomized } \\
\text { Double-blind } \\
\text { Placebo- } \\
\text { controlled } \\
\text { Parallel }\end{array}$ & 439 (19) & $74 \%$ & $12-65$ & 4 & Fexofenadine & $\begin{array}{l}40 \\
120 \\
240 \\
480\end{array}$ & $\begin{array}{l}\text { PS }(0-4) \\
\text { NWS (0-4) } \\
\text { TSS } \\
\text { Interference } \\
\text { with sleep and } \\
\text { daily activities } \\
(0-3)\end{array}$ & Yes & $2 \mathrm{a}$ & 3 \\
\hline $\begin{array}{l}\text { Nelson et al } \\
2000 \text { [11] }\end{array}$ & $\begin{array}{l}\text { Multicenter } \\
\text { Randomized } \\
\text { Double-blind } \\
\text { Placebo- } \\
\text { controlled } \\
\text { Clinical trial } \\
\text { Parallel }\end{array}$ & $418(136)$ & $70.09 \%$ & $12-65$ & 4 & Fexofenadine & $\begin{array}{l}40 \\
120 \\
240 \\
480\end{array}$ & $\begin{array}{l}\text { PS }(0-4) \\
\text { NWS }(0-4) \\
\text { Interference } \\
\text { with sleep and } \\
\text { daily activities } \\
(0-3)\end{array}$ & Yes & $2 a$ & 3 \\
\hline $\begin{array}{l}\text { Godse et al } \\
2010[12]\end{array}$ & $\begin{array}{l}\text { Single-center } \\
\text { Nonrandomized } \\
\text { Noncontrolled } \\
\text { Clinical trial }\end{array}$ & $\begin{array}{l}37 \\
\text { (unknown) }\end{array}$ & $46 \%$ & $18-60$ & 4 & Fexofenadine & $\begin{array}{l}180 \\
360 \\
540\end{array}$ & UAS & Yes & 4 & $\mathrm{NA}^{*}$ \\
\hline $\begin{array}{l}\text { Tanizaki } \\
\text { et al } 2013 \\
{[10]}\end{array}$ & $\begin{array}{l}\text { Single-center } \\
\text { Nonrandomized } \\
\text { Noncontrolled } \\
\text { Clinical trial }\end{array}$ & $\begin{array}{l}20 \\
\text { (unknown) }\end{array}$ & $40 \%$ & $\begin{array}{l}\text { Mean } \\
36,2\end{array}$ & 8 & Fexofenadine & $\begin{array}{l}120 \\
240\end{array}$ & $\begin{array}{l}\text { VAS } \\
\text { (pruritus) } \\
\text { Severity Index }\end{array}$ & Yes & $3 b$ & 0 \\
\hline $\begin{array}{l}\text { Magen et al } \\
2012[8]\end{array}$ & $\begin{array}{l}\text { Single-center } \\
\text { Nonrandomized } \\
\text { Noncontrolled } \\
\text { Clinical trial }\end{array}$ & $\begin{array}{l}276 \\
\text { (unknown) }\end{array}$ & NA & $>18$ & 16 & Fexofenadine & $\begin{array}{l}180 \\
360 \\
540 \\
720\end{array}$ & UAS & $\mathrm{NA}^{*}$ & $3 b$ & 0 \\
\hline $\begin{array}{l}\text { Kameyoshi } \\
\text { et al } 2007 \\
{[13]}\end{array}$ & $\begin{array}{l}\text { Multicenter } \\
\text { Randomized } \\
\text { Noncontrolled } \\
\text { Clinical trial }\end{array}$ & $\begin{array}{l}21 \\
\text { (unknown) }\end{array}$ & NA & $\begin{array}{l}\text { Mean } \\
\text { (Group } \\
\text { A) 42,5 } \\
\text { Mean } \\
\text { (Group } \\
\text { B) } 36,9\end{array}$ & $2-4$ & Cetirizine & $\begin{array}{l}20 \\
\text { (Group A) } \\
20-10 \\
\text { (Group B) }\end{array}$ & $\begin{array}{l}\text { NWS }(0-3) \\
\text { DWS }(0-3) \\
\text { Severity of } \\
\text { itch }(0-3) \\
\text { Total Score } \\
(0-9)\end{array}$ & $\mathrm{NA}^{*}$ & $3 b$ & 0 \\
\hline $\begin{array}{l}\text { Asero et al } \\
2007 \text { [14] }\end{array}$ & $\begin{array}{l}\text { Single-center } \\
\text { Nonrandomized }\end{array}$ & $22(0)$ & $13 \%$ & $28-67$ & 2 & Cetirizine & $\begin{array}{l}10 \\
30\end{array}$ & $\begin{array}{l}\text { VAS on } \\
\text { Urticaria } \\
\text { severity }\end{array}$ & Yes & $3 a$ & 2 \\
\hline \multirow[t]{2}{*}{$\begin{array}{l}\text { Staevska } \\
\text { et al } 2010 \\
{[16]}\end{array}$} & $\begin{array}{l}\text { Single-center } \\
\text { Randomized } \\
\text { Double-arm }\end{array}$ & $40(0)$ & $60 \%$ & $19-61$ & 3 & Levocetirizine & $\begin{array}{l}5 \\
10 \\
20\end{array}$ & $\begin{array}{l}\text { CU-Q2oL } \\
\text { VAS }\end{array}$ & Yes & $1 b-2 a$ & 3 \\
\hline & $\begin{array}{l}\text { Single-center } \\
\text { Randomized } \\
\text { Double-arm }\end{array}$ & $40(3)$ & $72 \%$ & $19-67$ & 3 & Desloratadine & $\begin{array}{l}5 \\
10 \\
20\end{array}$ & $\begin{array}{l}\text { CU-Q2oL } \\
\text { VAS }\end{array}$ & Yes & $1 b-2 a$ & 3 \\
\hline $\begin{array}{l}\text { Godse et al } \\
2010[15]\end{array}$ & $\begin{array}{l}\text { Single-center } \\
\text { Nonrandomized } \\
\text { Noncontrolled } \\
\text { Clinical trial }\end{array}$ & $\begin{array}{l}20 \\
\text { (unknown) }\end{array}$ & $60 \%$ & $20-60$ & 4 & Levocetirizine & $\begin{array}{l}5 \\
10 \\
20\end{array}$ & UAS & Yes & 4 & $\mathrm{NA}^{*}$ \\
\hline $\begin{array}{l}\text { Godse et al } \\
2011[17]\end{array}$ & $\begin{array}{l}\text { Single-center } \\
\text { Nonrandomized } \\
\text { Noncontrolled } \\
\text { Clinical trial }\end{array}$ & $30(3)$ & $53 \%$ & $20-60$ & 4 & Ebastine & $\begin{array}{l}10 \\
20 \\
40\end{array}$ & UAS & Yes & 4 & $\mathrm{NA}^{*}$ \\
\hline
\end{tabular}


Table 1. Global Evidence (continued)

\begin{tabular}{|c|c|c|c|c|c|c|c|c|c|c|c|}
\hline Study & Design & $\begin{array}{l}\text { No. of } \\
\text { Patients } \\
\text { (With- } \\
\text { drawn) }\end{array}$ & $\begin{array}{l}\text { Female } \\
\text { Sex, }\end{array}$ & Age, y & $\begin{array}{l}\text { Dura- } \\
\text { tion, } \\
\text { wk }\end{array}$ & Antihistamine & $\begin{array}{l}\text { Daily } \\
\text { Dosage, } \\
\text { mg }\end{array}$ & $\begin{array}{l}\text { Efficacy } \\
\text { Measures }\end{array}$ & Safety & Oxford & Jadad \\
\hline $\begin{array}{l}\text { Dubertret } \\
\text { et al } 2007 \\
{[18]}\end{array}$ & $\begin{array}{l}\text { Multicenter } \\
\text { Randomized, } \\
\text { Double-blind, } \\
\text { Placebo- } \\
\text { controlled, } \\
\text { Parallel }\end{array}$ & 277 (39) & $72.92 \%$ & $12-65$ & 4 & Rupatadine & $\begin{array}{l}5 \\
10 \\
20\end{array}$ & $\begin{array}{l}\text { PS (0-4) } \\
\text { NWS (0-4) } \\
\text { TSS } \\
\text { Perception } \\
\text { global of } \\
\text { efficacy (0-4) } \\
\text { Interference } \\
\text { with sleep } \\
\text { and daily } \\
\text { activities (0-3) }\end{array}$ & Yes & $2 \mathrm{a}$ & 3 \\
\hline $\begin{array}{l}\text { Giménez- } \\
\text { Arnau et al } \\
2007 \text { [2] }\end{array}$ & $\begin{array}{l}\text { Multicenter } \\
\text { Randomized } \\
\text { Double-blind } \\
\text { Placebo- } \\
\text { controlled } \\
\text { Parallel }\end{array}$ & $334(41)$ & $77 \%$ & $12-65$ & 4 y 6 & Rupatadine & $\begin{array}{l}10 \\
20\end{array}$ & $\begin{array}{l}\text { PS }(0-4) \\
\text { NWS }(0-4) \\
\text { TSS } \\
\text { DLQI } \\
\text { VAS (1-100) } \\
\text { Perception } \\
\text { global of } \\
\text { efficacy }(0-4)\end{array}$ & Yes & $1 b$ & 4 \\
\hline $\begin{array}{l}\text { Weller et al } \\
2018 \text { [20] }\end{array}$ & $\begin{array}{l}\text { Open-label } \\
\text { study }\end{array}$ & 29 & $79.3 \%$ & $20-85$ & 6 & Bilastine & $\begin{array}{l}20 \\
40 \\
80\end{array}$ & $\begin{array}{l}\text { UAS/UAS7 } \\
\text { Severity of } \\
\text { CSU }\end{array}$ & Yes & $3 a$ & $\mathrm{NA}^{\ddagger}$ \\
\hline
\end{tabular}

Abbreviations: CSU, chronic spontaneous urticaria; CU-Q2oL, Chronic Urticaria Quality of Life Questionnaire; DLQI, Dermatology Life Quality Index; DWS, Duration of Wheals Score; NA, not applicable; NWS, Number of Wheals Score; PS, Pruritus Score; TSS, Total Symptom Score; UAS, Urticaria Activity Score; UAS7, 7-day Urticaria Activity Score; VAS, visual analog scale.

of study participants ranged from 20 to 439 . The study on fexofenadine by Finn et al [7] had the largest number of patients. Duration was short in all studies (from 2 to 8 weeks), except for the study on fexofenadine by Magen et al [8], which lasted 16 weeks. Table 3 shows the licensed doses.

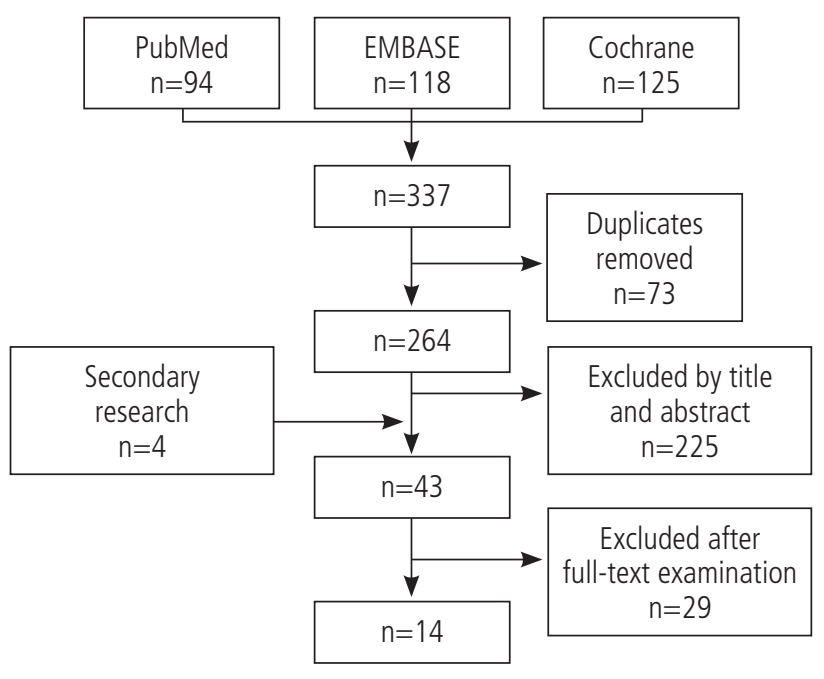

Figure. Study flow-chart.

\section{Fexofenadine}

Results for up-dosing of fexofenadine varied. A multicenter, double-blind, randomized, parallel-group, placebo-controlled study by Paul et al [9] analyzed 222 patients treated with fexofenadine or placebo at doses of $60 \mathrm{mg}, 120 \mathrm{mg}, 180 \mathrm{mg}$, and $240 \mathrm{mg}$ once daily for 6 weeks. The authors found that increasing the dose of fexofenadine to $180 \mathrm{mg}$ daily achieved better control. The efficacy measures were the mean daily total symptom score, which included the pruritus score, and number of wheals score. The 180-mg and 240-mg doses resulted in significant reductions in the total symptoms score and pruritus score compared with placebo, and the response was found to be dose-dependent. Significant reductions in the number of wheals were only observed in the $180-\mathrm{mg}$ treatment group. Since there were no significant differences between the $180-\mathrm{mg} / \mathrm{d}$ and $240-\mathrm{mg} / \mathrm{d}$ doses, the authors recommended fexofenadine $180 \mathrm{mg} / \mathrm{d}$ as the optimal dose. The most frequently reported treatment-related adverse event was headache, and no patients experienced drowsiness.

An uncontrolled clinical trial by Tanizaki et al [10] showed that increasing doses of fexofenadine from $120 \mathrm{mg}$ to $240 \mathrm{mg}$ daily reduced symptoms of CSU in 20 patients, with severity of pruritus assessed using a visual analog scale and the severity index. Skin responses to histamine induced by iontophoresis were also evaluated and seemed to be better suppressed with $240 \mathrm{mg}$. None of the patients reported adverse effects. 
Table 2. Results

\begin{tabular}{|c|c|c|c|c|c|c|}
\hline Study & Antihistamine & Results & $\begin{array}{l}\text { Difference } \\
\text { With High } \\
\text { Doses in } \\
\text { Urticaria } \\
\text { Control }\end{array}$ & \multicolumn{3}{|l|}{ Adverse Events } \\
\hline $\begin{array}{l}\text { Paul et al } \\
1998[9]\end{array}$ & Fexofenadine & $\begin{array}{l}\text { ANCOVA } \\
\text { Mean PS: Any dose better than placebo. Dose-dependent } \\
\text { effect } \\
\text { NWS: } 180 \mathrm{mg} \text { and } 240 \mathrm{mg} \text { daily doses superior to placebo } \\
\text { TSS: } 180 \mathrm{mg} \text { and } 240 \mathrm{mg} \text { daily doses are associated with } \\
\text { statistically significant values } \\
60 \mathrm{mg} / \mathrm{d} \text { and } 180 \mathrm{mg} / \mathrm{d} \text { are associated with better patient's } \\
\text { assessment of effectiveness } \\
\text { Only } 180 \mathrm{mg} / \mathrm{d} \text { is associated with better physician } \\
\text { assessment }\end{array}$ & $\begin{array}{l}\text { No } \\
\text { difference } \\
\text { between } \\
180 \text { and } \\
240 \mathrm{mg}\end{array}$ & \multicolumn{3}{|c|}{$\begin{array}{l}\text { Similar to or lower than placebo } \\
\text { Most frequently reported event: headache } \\
\text { (12\% in active group, } 14 \% \text { in placebo } \\
\text { group) } \\
\text { No relationship between doses }\end{array}$} \\
\hline $\begin{array}{l}\text { Finn et al } \\
1999[7]\end{array}$ & Fexofenadine & $\begin{array}{l}\text { ANCOVA } \\
\text { Mean PS: All doses superior to placebo } \\
\text { Mean NWS: All doses superior to placebo } \\
\text { Mean TSS: All doses superior to placebo } \\
\text { Interference with sleep and daily activities: All doses } \\
\text { superior to placebo } \\
\text { No statistical differences between doses }\end{array}$ & $\begin{array}{l}\text { No, except } \\
\text { for } 480 \\
\text { mg better } \\
\text { efficacy in } \\
\text { PS }\end{array}$ & \multicolumn{3}{|c|}{$\begin{array}{l}\text { Similar in all treatment groups and to } \\
\text { placebo } \\
\text { Most frequently reported event: headache }\end{array}$} \\
\hline $\begin{array}{l}\text { Nelson et al } \\
2000[11]\end{array}$ & Fexofenadine & $\begin{array}{l}\text { ANCOVA: } \\
\text { Mean PS: All doses superior to placebo, linear trend } \\
\text { Mean NWS: All doses fexofenadine doses superior to } \\
\text { placebo, dose-trend } \\
\text { Interference with sleep and daily activities: All dose group } \\
\text { better than placebo, linear trend } \\
\text { No statistical differences between doses }\end{array}$ & No & \multicolumn{3}{|c|}{$\begin{array}{l}\text { Similar in all treatment groups } \\
\text { Most frequently reported event: headache }\end{array}$} \\
\hline $\begin{array}{l}\text { Godse et al } \\
2010[12]\end{array}$ & Fexofenadine & $\begin{array}{l}\text { Symptom-free patients: } \\
180 \mathrm{mg} / \mathrm{d}: 11 / 37 \\
360 \mathrm{mg} / \mathrm{d}: 12 / 26 \\
540 \mathrm{mg} / \mathrm{d}: 13 / 14\end{array}$ & Yes & \multicolumn{3}{|c|}{$\begin{array}{l}\text { Headache }(2 / 37) \text { with } 540 \mathrm{mg} / \mathrm{d} \\
\text { Drowsiness }(1 / 37) \text { with } 540 \mathrm{mg} / \mathrm{d}\end{array}$} \\
\hline $\begin{array}{l}\text { Tanizaki } \\
\text { et al } 2013 \\
{[10]}\end{array}$ & Fexofenadine & $240 \mathrm{mg}: 100 \%$ VAS score and severity index decreased & Yes & \multicolumn{3}{|c|}{$\begin{array}{l}\text { None of the patients complained of fatigue } \\
\text { and/or sleepiness }\end{array}$} \\
\hline $\begin{array}{l}\text { Magen et al } \\
2012[8]\end{array}$ & Fexofenadine & $\begin{array}{l}180 \mathrm{mg}: \\
62.3 \%:>50 \% \text { improvement in UAS } \\
360-720 \mathrm{mg}: \\
75 \% \text { control urticaria } \\
25 \% \text { no control urticaria }\end{array}$ & Yes & \multicolumn{3}{|l|}{ NA } \\
\hline $\begin{array}{l}\text { Kameyoshi } \\
\text { et al } 2007 \\
{[13]}\end{array}$ & Cetirizine & $\begin{array}{l}\text { Better control of urticarial activity with } 20 \mathrm{mg} / \mathrm{d} \text { than } 10 \\
\mathrm{mg} / \mathrm{d}\end{array}$ & Yes & \multicolumn{3}{|l|}{$\begin{array}{l}\text { Drowsiness: } \\
20 \mathrm{mg} / \mathrm{d}: 2 \text { patients } \\
10 \mathrm{mg} / \mathrm{d} \text { : none }\end{array}$} \\
\hline $\begin{array}{l}\text { Asero et al } \\
2007[14]\end{array}$ & Cetirizine & Only 1 of 22 patients $(5 \%)$ reached clinical benefit & No & \multicolumn{3}{|c|}{$\begin{array}{l}\text { Tiredness and somnolence were reported } \\
\text { by } 13 \text { patients }(59 \%)\end{array}$} \\
\hline \multirow[t]{2}{*}{$\begin{array}{l}\text { Staevska } \\
\text { et al } 2010 \\
{[16]}\end{array}$} & Levocetirizine & $\begin{array}{l}\text { Levocetirizine responders: } \\
5 \mathrm{mg} / \mathrm{d}: 9 / 40 \\
10 \mathrm{mg} / \mathrm{d}: 8 / 40 \\
20 \mathrm{mg} / \mathrm{d}: 5 / 40\end{array}$ & Yes & $\begin{array}{l}\text { Somnolence: } \\
75 \% \text { no change } \\
\text { or reduction in } \\
\text { somnolence } \\
\text { No difference } \\
\text { with higher doses }\end{array}$ & \multirow{2}{*}{$\begin{array}{l}\text { Other side } \\
\text { effects (low } \\
\text { probability of } \\
\text { association } \\
\text { with the drug): } \\
\text { Hip pain, } \\
\text { anxiety, } \\
\text { nausea, } \\
\text { fatigue, } \\
\text { headache, oral } \\
\text { discomfort, } \\
\text { kidney pain, } \\
\text { stomac hache, } \\
\text { viral infection, } \\
\text { palpitations } \\
\text { (no changes in } \\
\text { ECG) }\end{array}$} & $15 \%$ \\
\hline & Desloratadine & $\begin{array}{l}\text { Desloratadine responders: } \\
5 \mathrm{mg} / \mathrm{d}: 4 / 40 \\
10 \mathrm{mg} / \mathrm{d}: 7 / 40 \\
20 \mathrm{mg} / \mathrm{d}: 1 / 20\end{array}$ & Yes & $\begin{array}{l}\text { Somnolence: } \\
55 \% \text { no change } \\
\text { or reduction in } \\
\text { somnolence } \\
\text { No difference } \\
\text { with higher doses }\end{array}$ & & $27.5 \%$ \\
\hline
\end{tabular}


Table 2. Results (continued)

\begin{tabular}{|c|c|c|c|c|}
\hline Study & Antihistamine & Results & $\begin{array}{l}\text { Difference } \\
\text { With High } \\
\text { Doses in } \\
\text { Urticaria } \\
\text { Control }\end{array}$ & Adverse Events \\
\hline $\begin{array}{l}\text { Godse et al } \\
2010[15]\end{array}$ & Levocetirizine & $\begin{array}{l}\text { Symptom free patients: } \\
5 \mathrm{mg} / \mathrm{d}(12 / 20) \\
10 \mathrm{mg} / \mathrm{d}(6 / 8) \\
20 \mathrm{mg} / \mathrm{d}(2 / 2)\end{array}$ & Yes & $\begin{array}{l}\text { Drowsiness: } \\
\text { 10-mg/d group: } 1 \text { patient } \\
\text { 20-mg/d group: } 1 \text { patient }\end{array}$ \\
\hline $\begin{array}{l}\text { Godse et al } \\
2011[17]\end{array}$ & Ebastine & $\begin{array}{l}\text { Symptom free patients: } \\
10 \mathrm{mg} / \mathrm{d}(17 / 27) \\
20 \mathrm{mg} / \mathrm{d}(8 / 10) \\
40 \mathrm{mg} / \mathrm{d}(2 / 2)\end{array}$ & Yes & $\begin{array}{l}\text { Mild sedation in } 1 \text { patient in } 40-\mathrm{mg} / \mathrm{d} \\
\text { group }\end{array}$ \\
\hline $\begin{array}{l}\text { Dubertret } \\
\text { et al } 2007 \\
{[18]}\end{array}$ & Rupatadine & $\begin{array}{l}\text { ANOVA } \\
\text { Mean PS: Doses of } 10 \text { and } 20 \mathrm{mg} \text { are superior to placebo } \\
\text { with a linear trend } \\
\text { Mean NWS: No differences between the } 10 \text { - and } 20 \text {-mg } \\
\text { doses, though dose-response effect was observed with } \\
\text { the } 20 \text {-mg dose } \\
\text { Mean TSS: } 10 \mathrm{mg} \text { and } 20 \mathrm{mg} \text { are superior to placebo } \\
\text { Dose of } 5 \mathrm{mg} \text { no significant differences compared to } \\
\text { placebo in these parameters } \\
\text { Perception global efficacy: } 10 \mathrm{mg} \text { and } 20 \mathrm{mg} \text { are associated } \\
\text { with better efficacy by investigators and patients } \\
\text { Interference with sleep and daily activities: } 10 \mathrm{mg} \text { and } \\
20 \mathrm{mg} \text { better to placebo, linear trend }\end{array}$ & $\begin{array}{l}\text { Yes, } \\
\text { between } 5 \\
\text { and } 10 / 20 \\
\text { not between } \\
10 \text { and } 20\end{array}$ & $\begin{array}{l}\text { Drowsiness }(2.90 \% \text { for placebo, } 4.29 \% \\
\text { for } 5 \mathrm{mg}, 5.41 \% \text { for } 10 \mathrm{mg} \text { and } 21.43 \% \\
\text { for } 20 \mathrm{mg}) \\
\text { Headache }(4.35 \% \text { for placebo, } 2.86 \% \text { for } \\
5 \mathrm{mg}, 4.05 \% \text { for } 10 \mathrm{mg} \text { and } 4.29 \% \text { for } \\
20 \mathrm{mg})\end{array}$ \\
\hline $\begin{array}{l}\text { Giménez- } \\
\text { Arnau et al } \\
2007 \text { [2] }\end{array}$ & Rupatadine & $\begin{array}{l}\text { ANOVA } \\
\text { Mean PS: Doses of } 10 \text { and } 20 \mathrm{mg} \text { are superior to placebo, } \\
\text { but not significantly different between } 10 \text { and } 20 \mathrm{mg} \\
\text { Mean NWS: Doses of } 10 \text { and } 20 \mathrm{mg} \text { are superior to placebo } \\
\text { from the first week, were not significantly different between } \\
10 \text { and } 20 \mathrm{mg} \\
\text { Mean TSS: Dose of } 10 \text { and } 20 \mathrm{mg} \text { were not significantly } \\
\text { different at any time } \\
\text { DLQI: } 20 \mathrm{mg} \text { improve all the subdomain scores to a greater } \\
\text { extent than placebo over the time } \\
\text { VAS: } 20 \mathrm{mg} \text { significantly decrease the baseline compared } \\
\text { to placebo, } 10 \text { mg also reduces it, although this was not } \\
\text { significant compared with placebo } \\
\text { Overall perception of efficacy: } 10 \text { and } 20 \text { mg are associated } \\
\text { with good/excellent improvement }\end{array}$ & No & $\begin{array}{l}\text { Headache }(8 \% \text { for placebo, } 4.5 \% \text { for } \\
10 \mathrm{mg} \text { and } 8.3 \% \text { for } 20 \mathrm{mg}) \\
\text { Drowsiness }(5.3 \% \text { for placebo, } 2.7 \% \text { for } \\
10 \mathrm{mg} \text { and } 8.3 \% \text { for } 20 \mathrm{mg})\end{array}$ \\
\hline $\begin{array}{l}\text { Weller et al } \\
2018[20]\end{array}$ & Bilastine & $\begin{array}{l}\text { UAS7 reduction: } \\
20 \mathrm{mg}: 37 \% \text { reduction from baseline } \\
40 \mathrm{mg}: 23 \% \text { further reduction after up-dosing } \\
80 \mathrm{mg}: 7 \% \text { further reduction after up-dosing, not } \\
\text { statistically significant }\end{array}$ & $\begin{array}{l}\text { Yes } \\
\text { between } 20 \\
\text { and } 40, \text { not } \\
\text { with } 80 \mathrm{mg}\end{array}$ & $\begin{array}{l}\text { Tiredness: } \\
20 \mathrm{mg} / \mathrm{d} \text { group: } 6 \text { patients } \\
40 \mathrm{mg} / \mathrm{d} \text { group: } 1 \text { patient } \\
80 \mathrm{mg} / \mathrm{d} \text { group: } 1 \text { patient }\end{array}$ \\
\hline
\end{tabular}

Abbreviations: ANCOVA, analysis of covariance; ANOVA, analysis of variance; CSU, chronic spontaneous urticaria; NA, not applicable; DLQI, Dermatology Life Quality Index; NA, not applicable; NWS, Number of Wheals Score; PS, Pruritus Score; TSS, Total Symptom Score; UAS, Urticaria Activity Score; UAS7, 7-day Urticaria Activity Score; VAS, visual analog scale.

On the other hand, Finn et al [7] reported no differences in urticaria control despite increased doses of fexofenadine. The authors reported similar efficacy in the 60-mg, 120-mg, and 240-mg twice daily groups. Their multicenter, doubleblind, randomized trial compared fexofenadine with placebo in 439 patients treated with fexofenadine at doses of $20 \mathrm{mg}$, $60 \mathrm{mg}, 120 \mathrm{mg}$, and $240 \mathrm{mg}$ twice daily for 4 weeks. All doses of fexofenadine were statistically superior to placebo for disease control (reduction in pruritus and number of wheals), and there was less interference with sleep and daily activities than with placebo. The twice-daily $240-\mathrm{mg}$ doses proved more efficacious $(64 \%)$ for reducing pruritus. The incidence of adverse effects was similar in all groups, with headache being the most frequently reported.

Nelson et al [11] performed a similar study to that of Finn et al [7], again, for 4 weeks, with 418 patients taking fexofenadine $20 \mathrm{mg}, 60 \mathrm{mg}, 120 \mathrm{mg}$, and $240 \mathrm{mg}$ twice daily. A total of 282 patients completed the study. All fexofenadine doses led to significant relief of urticaria symptoms compared with placebo, except for $20 \mathrm{mg}$ twice daily, which seems to be suboptimal. In all efficacy measures, $60 \mathrm{mg}$ twice daily had a similar effect to $240 \mathrm{mg}$ twice daily. The results of this study 
Table 3. Antihistamines Evaluated and Licensed Daily Doses

\begin{tabular}{lc}
\hline Antihistamines & Maximum Licensed Doses, mg/d \\
\hline Desloratadine & $5 \mathrm{mg} / \mathrm{d}$ \\
Loratadine & $10 \mathrm{mg} / \mathrm{d}$ \\
Levocetirizine & $5 \mathrm{mg} / \mathrm{d}$ \\
Cetirizine & $10 \mathrm{mg} / \mathrm{d}$ \\
Ebastine & $20 \mathrm{mg} / \mathrm{d}$ \\
Fexofenadine & $180 \mathrm{mg} / \mathrm{d}$ \\
Rupatadine & $10 \mathrm{mg} / \mathrm{d}$ \\
Bilastine & $20 \mathrm{mg} / \mathrm{d}$
\end{tabular}

Source: Agencia Española de Medicamentos y Productos Sanitarios (AEMPS):

Data sheet desloratadine (Revised May 27, 2020). In:

https://cima.aemps.es/cima/pdfs/es/ft/76344/FT_76344.html.pdf

Data sheet loratadine. (Revised May 27, 2020). In:

https://cima.aemps.es/cima/pdfs/es/ft/58518/FT_58518.pdf

Data sheet levocetirizine. (Revised May 27, 2020).

In: http://cima.aemps.es/cima/pdfs/es/ft/64287/64287_ft.pdf

Data sheet cetirizine. (Revised May 27, 2020).

In: https://cima.aemps.es/cima/pdfs/es/ft/58481/FT_58481.pdf

Data sheet ebastine. (Revised May 27, 2020). In:

https://cima.aemps.es/cima/pdfs/es/ft/63366/FichaTecnica_63366.html.pdf

Data sheet fexofenadine. (Revised May 27, 2020). In:

https://cima.aemps.es/cima/pdfs/es/ft/79718/79718_ft.pdf

Data sheet rupatadine. (Revised May 27, 2020). In:

https://cima.aemps.es/cima/pdfs/es/p/64053/P_64053.pdf

Data sheet bilastine. (Revised May 27, 2020). In:

https://cima.aemps.es/cima/pdfs/es/ft/73027/FT_73027.html.pdf

suggest that fexofenadine $60 \mathrm{mg}$ twice daily $(120 \mathrm{mg} / \mathrm{d})$ is the optimal effective dose. All doses had a similar safety profile.

Godse et al [12] performed a nonrandomized, uncontrolled clinical trial for 4 weeks in 37 patients, all of whom started with fexofenadine $180 \mathrm{mg}$ and were reviewed at weekly intervals for 4 weeks. For symptomatic patients, the dose of fexofenadine was doubled to $360 \mathrm{mg}$ at the end of week 1 and $540 \mathrm{mg}$ at the end of week 2 . The authors recorded the Urticaria Activity Score (UAS). Adverse effects were sedation in 1 patient and headache in 2 patients at higher doses. Urticaria was controlled with higher-dose fexofenadine in most patients.

In an uncontrolled nonrandomized open-label clinical trial, Magen et al [8] prospectively studied 276 patients who started therapy with fexofenadine $180 \mathrm{mg} / \mathrm{d}$. At week 8 , the UAS had improved by $\geq 50 \%$ from baseline, and treatment was continued. In 83 patients, whose improvement in UAS at week 8 was $\leq 50 \%$, fexofenadine was increased to 2,3 , or 4 tablets per day every 7 days for 16 weeks. A significant benefit was observed in most cases after up-dosing to 2 or 3 tablets, although 21 patients $(25 \%)$ continued to experience urticaria despite increasing their dose to $720 \mathrm{mg}$.

\section{Cetirizine}

Cetirizine seems to be more effective with increasing doses. Kameyoshi et al [13] proposed that increasing cetirizine doses may lead to better control of urticaria activity in patients who did not respond to initial doses. The authors performed a study including 21 patients with a poor response to $10 \mathrm{mg}$ daily over a 1- to 2-week screening period. Patients were randomly assigned to group A or group B. Initially, all patients were given an increased dose of $20 \mathrm{mg}$ daily for 1 or 2 weeks. Patients in group A then continued with cetirizine $20 \mathrm{mg}$, and group B received $10 \mathrm{mg}$ for 1 to 2 weeks. Both groups recorded their UAS (number and duration of wheals and severity of itch). The scores were significantly lower in both groups while treated with $20 \mathrm{mg}$, although they improved in group A when $20 \mathrm{mg}$ was maintained in the second period. In group B, the UAS was higher while the dose was being reduced in the second period. Only 2 patients complained of drowsiness with the increased dose.

Asero [14] studied 22 patients who did not respond to cetirizine $10 \mathrm{mg}$ and concluded, after increases to $30 \mathrm{mg}$ daily for 1 week, that the number of patients with severe CSU who responded to an off-label dosage was very low, as they only observed a clinical benefit in 1 of them. Thirteen patients $(59 \%)$ reported tiredness and somnolence with $30 \mathrm{mg}$.

\section{Levocetirizine}

Godse et al [15] found levocetirizine to be more effective when the dose was increased. The authors performed a single-center, nonrandomized, uncontrolled clinical trial with levocetirizine $5 \mathrm{mg}, 10 \mathrm{mg}$, or $20 \mathrm{mg}$ daily in 20 patients for 4 weeks, with doses increasing in the first 2 weeks depending on the degree of control of urticaria. The authors recorded UAS at day 0 and week 2 . The percentage of patients who achieved control with $5 \mathrm{mg}, 10 \mathrm{mg}$, and $20 \mathrm{mg}$ was $60 \%, 30 \%$, and $10 \%$, respectively. Only $10 \%$ of patients needed a 4 -fold dose of levocetirizine for their disease to be controlled. The adverse events recorded were mild sedation in 2 patients with doses of 10 and $20 \mathrm{mg}$.

In their randomized, double-blind cross-over study, Staevska et al [16] analyzed the efficacy of increasing doses of levocetirizine and desloratadine if control was not achieved. In our review, we decided to analyze the first part of their study and both antihistamines separately. The study recruited 80 patients, 40 for each antihistamine.

Levocetirizine doses started at $5 \mathrm{mg}$, increasing weekly to 10 and $20 \mathrm{mg}$ if symptoms were not controlled. Nine patients responded to $5 \mathrm{mg}, 8$ to $10 \mathrm{mg}$, and 5 to $20 \mathrm{mg}$. The proportion of responders reporting more than $50 \%$ improvement in discomfort was $52 \%, 65 \%$, and $74 \%$ with 5,10 , and $20 \mathrm{mg}$, respectively. Regarding adverse effects, $75 \%$ of patients were not affected by somnolence, and patients taking $20 \mathrm{mg}$ did not report more somnolence than with lower doses. Six patients complained of adverse reactions, most of them not drug-related.

Desloratadine doses started at $5 \mathrm{mg}$, increasing weekly to 10 and $20 \mathrm{mg}$ if symptoms were not controlled. Four patients responded to $5 \mathrm{mg}, 7$ to $10 \mathrm{mg}$, and 1 to $20 \mathrm{mg}$. The proportion of responders reporting more than $50 \%$ improvement in discomfort was $41 \%, 56 \%$, and $63 \%$ with 5,10 , and $20 \mathrm{mg}$, respectively. Somnolence was not recorded in 55\%. As with levocetirizine, 4-fold increased doses did not affect somnolence. Eleven patients complained of adverse reactions, most of them not drug-related. 
One patient experienced palpitations, although no ECG abnormalities were observed.

\section{Ebastine}

Godse et al [17] performed a single-center, nonrandomized, uncontrolled clinical trial with 30 patients for 4 weeks to examine the efficacy of ebastine. All patients started with ebastine $10 \mathrm{mg}$ and were reviewed at weekly intervals. In symptomatic patients, the dose of ebastine was doubled to $20 \mathrm{mg}$ at the end of week 1 and $40 \mathrm{mg}$ at the end of week 2 . The UAS was recorded. Only 1 patient reported mild sedation with $40 \mathrm{mg}$. The authors concluded that $20 \mathrm{mg}$ of ebastine seemed superior to $10 \mathrm{mg}$. Urticaria was controlled with 40 $\mathrm{mg}$ in the 2 patients who remained symptomatic with $20 \mathrm{mg}$.

\section{Rupatadine}

In a multicenter, randomized, placebo-controlled trial in 277 patients treated with rupatadine at doses of $5 \mathrm{mg}, 10 \mathrm{mg}$, or $20 \mathrm{mg}$ once daily for 4 weeks, Dubertret et al [18] found that rupatadine 10 and $20 \mathrm{mg}$ provided fast and long-lasting relief from itching and symptoms, although a clear doseresponse effect was observed in favor of the 20-mg dose. Therefore, the minimum daily dose capable of effectively relieving itching and symptoms at 4 weeks was $10 \mathrm{mg}$. Both the investigators and the patients found rupatadine $10 \mathrm{mg}$ and $20 \mathrm{mg}$ to significantly improve the interference of urticaria symptoms with daily activities and sleep.

In a second study with a similar design, 334 patients were randomized to rupatadine $10 \mathrm{mg}, 20 \mathrm{mg}$, or placebo once daily for 4-6 weeks. Giménez-Arnau et al [2] found no difference in efficacy between the doses. Rupatadine at 10 and $20 \mathrm{mg}$ significantly reduced the severity of urticaria, showing rapid therapeutic action with objective clinical improvement as early as 7 days after treatment. This improvement persisted during the 6 weeks of the clinical trial. No significant differences in efficacy were observed between the 10-mg dose and the 20-mg dose, and a better adverse effect profile was recorded. Rupatadine $10 \mathrm{mg}$ is useful and safe in the management of urticaria.

Lastly, Giménez-Arnau et al [19] published the results of a study analyzing pooled data from the 2 previous trials. A total of 538 patients were included. Responder rates were defined as the percentage of patients who exhibited a reduction in symptoms by at least $50 \%$ or $75 \%$ compared to baseline after 4 weeks of treatment. The authors evaluated pruritus, mean number of wheals, and mean UAS. The study concluded that both doses of rupatadine, 10 and $20 \mathrm{mg}$, elicited a significantly superior response with respect to placebo, although more patients obtained a $75 \%$ improvement with the $20-\mathrm{mg}$ dose. In summary, according to this study, there is evidence of a somewhat greater effect with rupatadine $20 \mathrm{mg}$ daily.

\section{Bilastine}

In an open-label study, Weller et al [20] depicted the effects of bilastine at $20 \mathrm{mg}, 40 \mathrm{mg}$, and $80 \mathrm{mg}$ daily in 3 consecutive 2 week-periods. A total of $29 \mathrm{CSU}$ patients were treated with an initial dose of $20 \mathrm{mg}$ that was increased to $40 \mathrm{mg}$ after 2 weeks in patients with UAS7 $>3$; the same criteria were adopted 2 weeks later with $80 \mathrm{mg}$. The authors concluded that bilastine at the standard dose was effective and that up-dosing to double the licensed dose appeared to be sufficient for most of patients. Tiredness was reported by 6 patients receiving $20 \mathrm{mg}$ bilastine, although only by 1 at $40 \mathrm{mg}$ and by 1 at $80 \mathrm{mg}$.

\section{Quality Assessment of the Studies Included in the Review}

The quality of the studies included was variable. Only 5 were placebo-controlled (Paul et al [9], Finn et al [7], Nelson et al [11], Dubertret et al [18], and Giménez-Arnau et al [2]) and 5 had a Jadad score $\geq 3$. The studies performed by Godse et al [12,15,17], Kameyoshi et al [13], and Weller et al [20] analyzed up-dosing responses in patients who did not respond to standard doses.

\section{Discussion}

In this review, as clinicians, we tried to answer 2 questions: Is there enough scientific evidence for up-dosing? Is it really safe to prescribe off-label doses?

International guidelines on the management of CSU support up-dosing second-generation antihistamines to 4-fold the licensed dose when control is not achieved. However, this recommendation is based mainly on expert opinion, and large well-designed double-blind clinical trials are lacking.

Regarding efficacy, we analyzed 14 articles, of which only 6 were of high quality and 5 were placebo controlled. These corresponded to fexofenadine and rupatadine. No placebo effect was analyzed with the other antihistamines (levocetirizine, cetirizine, ebastine, and bilastine).

Unfortunately, the heterogeneity of the studies included (definition of control, design, quality, lack of active comparator, small sample size, outcomes) and their short duration made comparisons difficult.

As in the review by Ferrer et al [21], and similar to the systematic review and meta-analysis by Guillén-Aguinaga et al [4], who found that licensed doses control disease in $31 \%$ of patients and up-dosing controls symptoms in only $63.2 \%$, we found a predominance of studies that do not report significant differences for up-dosing. Therefore, we can conclude that while up-dosing fexofenadine can be considered good clinical practice, the limitations of the studies reviewed mean that more research is needed to confirm the observations made. Three were published almost 20 years ago, and the doses they recommended (180 $\mathrm{mg}$ or $120 \mathrm{mg}$ depending on the study) are the licensed doses today. Magen et al [8] reported better control when up-dosing to 360 and $720 \mathrm{mg}$ [8]. Finn et al [7] found no additional benefit except for the pruritus score with $480 \mathrm{mg}$. These findings are similar to those reported in the meta-analysis by Guillén-Aguinaga et al [4], who found no differences in wheal number or response rates, although they did record significant differences in control of pruritus.

In the case of rupatadine, $20 \mathrm{mg}$ is the optimal dose recommended by Giménez-Arnau et al [19], who analyzed pooled data from 2 studies $[2,18]$. However, when the studies were examined separately, these differences were not significant. There is no additional information about 4-fold up-dosing in CSU, although up-dosing of rupatadine to 4-fold 
has been reported to be effective in chronic inducible urticaria such as cold urticaria. Abajian et al [22] showed that $30 \%$ and $50 \%$ of patients with cold urticaria did not develop wheals during testing with TempTest 3.0 after treatment with 2-fold $(20 \mathrm{mg})$ and 4-fold (40 $\mathrm{mg})$ standard rupatadine dosages for 7 days, respectively. However, no significant differences were detected between 20 and $40 \mathrm{mg}$ of rupatadine in reduction of the cold temperature threshold or prolongation of the cold stimulation time threshold. Metz et al [23] found that 52\% of patients were complete responders when receiving $20 \mathrm{mg}$ (2-fold) of rupatadine for 7 days compared with only $5 \%$ in the placebo group [23].

The comparative analysis by Sanchez-Borges et al [24] confirms our results, namely, that doubling doses of fexofenadine and rupatadine leads to an objective improvement in most of the patients who responded to antihistamine.

In the case of cetirizine, of the 2 studies we selected, evidence to recommend up-dosing was insufficient, as Kameyoshi et al [13] only doubled the licensed dose and Asero [14] did not find any benefit in 3- or 4-fold increased doses.

Further evidence is also needed to recommend up-dosing in CSU with levocetirizine, desloratadine, bilastine, and ebastine. The quality of these studies and the short duration of treatment prevent us from stating a benefit, although our clinical experience confirms that up-dosing benefits patients who remain symptomatic.

Our review showed that measures of safety between studies are not stated or are unclear. Furthermore, adverse events were insufficiently evaluated. However, our findings are consistent with those of Sanchez-Borges et al [24] in that no predictable or new adverse effects could be identified. In the highest-quality studies, it seems that adverse events are similar in all the groups for the different doses and placebo. Relevant clinical data, such as hepatic enzyme and electrocardiographic values, are not collected. The lack of patients in specific situations (eg, elderly, polypharmacy, renal or hepatic impairment, heart disease) might limit safety for healthy volunteers or patients without comorbidities. Headache was the most frequent adverse event reported with fexofenadine and rupatadine across the studies, although the results are similar to those observed with placebo. Tiredness was reported by Godse et al [17] in some patients with ebastine, although, as shown previously, this did not seem to be dose-related. Drowsiness was also reported with cetirizine at double the licensed dose. Somnolence and sedation were uncommon, except in patients treated with rupatadine $20 \mathrm{mg}$. Staevska et al [16] reported that higher doses of desloratadine and levocetirizine led to a paradoxical decrease in somnolence, which was attributed to symptomatic relief. The short treatment duration in all the studies (except in that of Magen et al [8] for fexofenadine, which was 16 weeks) may be insufficient to draw conclusions from our observations, although up-dosing is accepted in real-life practice and no severe adverse effects are reported.

\section{Conclusion}

While up-dosing is effective and safe when we prescribe antihistamines in daily clinical practice according to current guidelines in CSU, our review shows that currently, there is little evidence for the efficacy and safety of high-dose $\mathrm{H}_{1}$ antihistamines in CSU. Most findings are based on expert opinion, few randomized controlled trials, and low-quality clinical studies. Our analysis revealed evidence for up-dosing to 2-fold (rupatadine, fexofenadine) or 3-fold. As for licensed doses of second-generation antihistamines in CSU in Spain, there is insufficient evidence to support up-dosing to 4-fold. Most studies did not evaluate safety data or provide long-term data.

High-quality and well-designed studies are needed to validate recommendations in guidelines and to determine optimal nonsedating antihistamines, optimal dose, and duration of treatment in patients not responding to standard treatment.

\section{Acknowledgments}

The authors would like to thank Dr Estíbaliz Loza for her contribution to the project and Novartis for providing the space for our meetings.

\section{Funding}

The authors declare that no funding was received for the present study.

\section{Conflicts of Interest}

Dr. Usero Bárcena reports the following: nonfinancial support from Novartis during the conduct of the study; personal fees and nonfinancial support from NOVARTIS, nonfinancial support from Almirall, nonfinancial support from Sanofi, nonfinancial support from AbbVie, nonfinancial support from Janssen, outside the submitted work.

Dr. Otero Rivas reports personal fees and nonfinancial support from Novartis during the conduct of the study.

The remaining authors declare that they have no conflicts of interest.

\section{References}

1. Sharma M, Bennett C, Carter B, Cohen SN. H1-antihistamines for chronic spontaneous urticaria: an abridged Cochrane Systematic Review. J Am Acad Dermatol. 2015;73(4):710-6.

2. Giménez-Arnau A, Pujol RM, lanosi S, Kaszuba A, Malbran A, Poop G, et al. Rupatadine in the treatment of chronic idiopathic urticaria: a double-blind, randomized, placebocontrolled multicentre study. Allergy. 2007;62(5):539-46.

3. Zuberbier $T$, Aberer $W$, Asero R, Abdul Latiff AH, Baker $D$, Ballmer-Weber $B$, et al. The EAACI/GA2LEN/EDF/WAO guideline for the definition, classification, diagnosis and management of urticaria. Allergy. 2018;73(7):1393-414.

4. Guillén-Aguinaga $S$, Jáuregui Presa I, Aguinaga-Ontoso E, Guillén-Grima F, Ferrer M. Updosing nonsedating antihistamines in patients with chronic spontaneous urticaria: a systematic review and meta-analysis. $\mathrm{Br} J$ Dermatol. 2016;175(6):1153-65.

5. Howick J, Chalmers I, Glasziou P, Greenhalgh T, Heneghan C, Liberati A, et al. "The 2011 Oxford CEBM Evidence Levels of Evidence (Introductory Document)". Oxford Centre for Evidence-Based Medicine. 
6. Jadad AR, Moore RA, Carroll D, Jenkinson C, Reynolds DJ, Gavaghan DJ, et al. Assessing the quality of reports of randomized clinical trials: is blinding necessary? Control Clin Trials. 1996;17(1):1-12.

7. Finn AF, Kaplan AP, Fretwell R, Qu R, Long J. A double-blind, placebo-controlled trial of fexofenadine $\mathrm{HCl}$ in the treatment of chronic idiopathic urticaria. J Allergy Clin Immunol. 1999;104(5):1071-8.

8. Magen E, Mishal J, Zeldin Y, Schlesinger M. Antihistamines do not inhibit the wheal induced by the intradermal injection of autologous serum in resistant chronic idiopathic urticaria. Allergy Asthma Proc. 2012;33(6):531-7.

9. Paul E, Berth-Jones J, Ortonne J-P. Fexofenadine hydrocholride in the treatment of chronic idiopathic urticaria: a placebocontrolled, parallel-group, dose-ranging study. J Dermatol Treat. 1998;101:410-20.

10. Tanizaki H, Nakahigashi K, Miyachi Y, Kabashima K. Comparison of the efficacy of fexofenadine $120 \mathrm{mg}$ and 240 mg per day on chronic idiopathic urticaria and histamineinduced skin responses in Japanese populations. J Dermatolg Treat. 2013;24:477-80.

11. Nelson HS, Reynolds R, Mason J. Fexofenadine $\mathrm{HCl}$ is safe and effective for treatment of chronic idiopathic urticaria. Ann Allergy Asthma Immunol. 2000;84(5):517-22.

12. Godse KV, Nadkarni NJ, Jani G, Ghate S. Fexofenadine in higher doses in chronic spontaneous urticaria. Indian Dermatol Online J. 2010;1(1):45-6.

13. Kameyoshi Y, Tanaka T, Mihara S, Takahagi S, Niimi N, Hide M. Increasing the dose of cetirizine may lead to better control of chronic idiopathic urticaria: an open study of 21 patients. Br J Dermatol. 2007;157(4):803-4.

14. Asero R. Chronic unremitting urticaria: is the use of anthistamines above the licensed dose effective? A preliminary study of cetirizine at licensed and above-licensed doses. Clin Exp Dermatol.2007;32:34-8.

15. Godse KV. Updosing of antihistamines to improve control of chronic urticaria. Indian J Dermatol Venereol Leprol. 2010;76(1):61-2

16. Staevska M, Popov TA, Kramalimarkova T, Lazarova C, Kraeva $S$, Popova $D$, et al. The effectiveness of levocetirizine and desloratadine in up to 4 times conventional doses in difficultto-treat urticaria. J Allergy Clin Immunol. 2010;125:676-82.

17. Godse KV. Ebastine in chronic spontaneous urticaria in higher doses. Indian J Dermatol. 2011;56(5):597-8.
18. Dubertret L, Zalupca L, Cristodoulo T, Benea V, Medicna I, Fantin $\mathrm{S}$, et al. Once-daily rupatadine improves the symptoms of chronic idiopathic urticaria: a randomised, double-blind, placebo-controlled study. Eur J Dermatol. 2007;17:223-8.

19. Giménez-Arnau A, Izquierdo I, Maurer M. The use of a responder analysis to identify clinically meaningful differences in chronic urticaria patients following placebo-controlled treatment with rupatadine 10 and $20 \mathrm{mg}$. J Eur Acad Dermatol Venereol. 2009;23:1088-91.

20. Weller K, Church MK, Hawro T, Altrichter S, Labeaga L, Magerl $\mathrm{M}$, et al. Updosing of bilastine is effective in moderate to severe chronic spontaneous urticaria: A real-life study. Allergy. 2018;73(10):2073-5.

21. Ferrer M, Sastre J, Jáuregui I, Dávila I, Montoro J, del Cubillo A et al. Effect of Antihistamine Up-Dosing in Chronic Urticaria. J Investig Allergol Clin Immunol. 2011;21(3):34-9.

22. Abajian M, Curto-Barredo L, Krause K, Santamaria E, Izquierdo I, Church MK, et al. Rupatadine $20 \mathrm{mg}$ and $40 \mathrm{mg}$ are Effective in Reducing the Symptoms of Chronic Cold Urticaria. Acta Derm Venereol. 2016;96(1):56-9.

23. Metz M, Scholz E, Ferrán M, Izquierdo I, Giménez-Arnau A, Maurer M. Rupatadine and its effects on symptom control, stimulation time, and temperature thresholds in patients with acquired cold urticaria. Ann Allergy Asthma Immunol. 2010;104(1):86-92.

24. Sánchez-Borges M, Ansotegui I, Montero Jimenez J, Rojo MI, Serrano C, Yañez A. Comparative efficacy of non-sedating antihistamine updosing in patients with chronic urticaria. World Allergy Organ J. 2014;7:33.

- Manuscript received June 4, 2020; accepted for publication October 7, 2020.

\section{Beatriz Veleiro Pérez}

Allergology Department

Complexo Hospitalario Universitario A Coruña

Xubias de Arriba, 84

15006 A Coruña, Spain

E-mail: beatriz.veleiro.perez@sergas.es 